\title{
Application of selected methods of multicriterial assessment \\ sciendo in the selection process of equipment used at the extraction \\ face - case study
}

doi:10.2478/mape-2019-0003

Date of submission to the Editor: 04/2018

Date of acceptance by the Editor: 07/2018

MAPE 2019, volume 2, issue 1, pp. 31-37

\section{Zygmunt Korban ${ }^{*}$}

ORCID.ID: 0000-0003-4312-847X

Silesian University of Technology, Poland

\section{INTRODUCTION}

The decision-making process is in most cases a complex process, which comprises the following (Chmiela \& Przybyła, 1997):

- identification of the problem,

- identification of the assessment criterion or criteria (of a selection),

- defining possible decisions (decision variants) and consequences of a selection,

- selection of the optimal (most favorable in terms of the accepted criterion or criteria) decision-making variant,

- analysis of the sensitivity of the made decisions.

In decision-making processes, mathematical methods are becoming more and more commonly used. This trend can be primarily explained by practical reasons: these methods allow to control the processes comprised within one integrated system, which ensures the coordination of actions at various levels. The literature emphasizes the fact that mathematical methods are useful for the manager, because they (Przybyła \& Korban, 2003, Przybyła \& Korban, 2004):

- enable the processing of more information and enrich the resource of information with new, additional order relations or association relations,

- improve and accelerate the processing of information, and thus facilitate the manager's active handling of information contained in the memory,

- enrich the rulebook by means of which the manager can process information into comprehensive action programs.

The challenges undertaken by the decision maker are mainly of a probabilistic nature, and therefore, every decision maker must be aware of the risks involved in making a particular decision. The following attributes can contribute to the reduction of risk (Kozdrój \& Przybyła, 1986):

- access to fast, current, accurate and "synthetic" information,

- progressively higher applicability of numerical information,

\footnotetext{
‘ zygmunt.korban@polsl.pl
} 
- wide application of information technology for the needs of data acquisition and processing (simulation methods of economic processes, methods of active control of processes, forecasting methods, etc.).

Since the extent to which the intended objective has been obtained is measured by the function of the objective (criterion function), we can speak about both singlecriterion (simple) and multi-criteria (complex) tasks. In the case of multicriteria (complex) methods, we assess not only the set of decision variants (objects) $W=\{W i$ : $i=1,2,3 \ldots, n\}$ subjected to assessment and the set of accepted assessment criteria $K=\{K j: j=1,2,3 \ldots, m\}$ (often comprising the weighs (significance) assigned to particular criteria), which allows to build the matrix $X$ being a measure of the variant $W_{i}$ according to the criterion $K_{j}($ Geneletti, 2005):

$$
X=\left[\begin{array}{ccc}
x_{11} & \cdots & x_{1 m} \\
\vdots & \ddots & \vdots \\
x_{m 1} & \cdots & x_{n m}
\end{array}\right]
$$

where:

$n$ - number of decision variant (object),

$m$ - number of assessment criterion.

As part of the assessment, both quantitative and qualitative criteria may be used, but in the case of qualitative criteria, the criteria must be quantified.

\section{CHARACTERISTIC OF SELECTED MULTICRITERIA METHODS}

In the group of multicriteria assessment methods we can distinguish methods of vector linear programming, purposive programming, scalarization and so-called discrete methods. The following methods will be used within the framework of this study: the Hellwig's development measure method and the Promethee II method.

\section{Hellwig's development measure method}

The Hellwig's method of development measure uses taxonomic (Euclidean) distances and synthesizes information (diagnostic variables). The following is defined in this method (Hellwig, 1968):

- an abstract point $P_{o}$ illustrating the model solution, having the coordinates

$\left\{x_{01}, x_{02}, \ldots \ldots \ldots \ldots . . . . . x_{0 m}\right\}$ meeting the conditions:

$$
\begin{array}{lr}
x_{o j}=\max x_{i j} & \text { when } j \in S \\
x_{o j}=\min x_{i j} & \text { when } j \in D
\end{array}
$$

where:

$S-$ a set of stimulants (features, variables whereof high values are desirable from the point of view of the problem being diagnosed, while low values are undesirable);

$D$ - a set of destimulants (features, variables, whereof low values, unlike in the case

of stimulants, are desirable from the point of view of the problem being diagnosed),

points $P_{i}$, which are a graphical interpretation of objects subjected to assessment. The distance between particular points $P_{i}$ and the point $P_{o}$ is determined by the dependence (Hellwig, 1968):

$$
C_{i o}=\sqrt{\sum_{j=1}^{m} \alpha_{j}\left(x_{i j}^{\prime}-x_{o j}^{\prime}\right)^{2}}
$$


where:

$x_{i j}^{\prime}$ - normalized coordinates of the point $P_{i}$;

$\alpha_{j}$ - significance (rank) of the $j$-th partial feature determined on the basis of the experts' opinion survey.

The essential condition enabling the determination of the above mentioned measure is to normalize the output variables whereof objective is (Mynarski, 1992):

- to bring the variables with different denominations to comparability (postulate of additivity),

- to unify the nature of variable features (postulate of uniform preferences),

- to eliminate non-positive values (postulate of positivity),

- to replace different ranges of features variability with constant ranges (postulate of constancy of the range or constancy of extreme values).

The value of the development measure was calculated from the following dependence (Hellwig, 1968):

$$
m_{i}=1-\frac{c_{i o}}{c_{\text {io } \operatorname{maz}}}
$$

where $m_{i} \in \leq 0 ; 1 \geq$.

It is assumed that the object is getting more developed, the more its value approaches the value of 1 .

\section{Promethee II METHOD}

As part of discrete multicriteria decision support methods we can distinguish, among others, the methods from the group Preference Ranking Organization Method for Enrichment Evaluations: PROMETHEE I, PROMETHEE II, PROMETHEE II + veto (the modifications of PROMETHEE methods include the methods: EXtension of the PROMethee method (EXPROM), EXPROM II + veto, EXPROM II + veto + SD and PROMETHEE II + veto + SD) (Abedi et al., 2012, Brans, 1982, Brans et al., 1986, Brans \& Vincke, 2005, Diakoulaki \& Koumoutsos, 1991, Górecka, 2010, Górecka \& Muszyńska, 2011, Górecka \& Szałucka, 2013, Nowak, 2005, Roy, 1990, Vijay \& Shankar, 2010, Vincke, 1992). In the Promethee II method used in the example, the decision maker defines a finite set of decision variants (objects), from which he wants to obtain a variant (object) best suited to his preferences (Figueira et al., 2005). In this method, the maximized criteria are considered and the decision variants themselves $(a, b, c, \ldots n)$ are compared in pairs with regard to the $i$-th criterion. The decision maker's preferences are determined on the basis of the obtained differences, i.e. preference functions are defined as a generalized criterion related to the $i$-th criterion. The values of the preferences are in the interval $[0$; 1], where the value 1 (or close to 1 ) indicates a strong preference of one variant in relation to the other; the value 0 (or values close to 0 ) - indicates a negligible preference.

In addition, the significance coefficients $w_{i}$ are assigned to the individual criteria, with $\sum_{i=1}^{n} w_{i}=1$. 


\section{APPLICATION OF MULTICRITERIAL ASSESSMENT METHODS IN THE PROCESSES OF MULTI-VARIANT DESIGNING OF TECHNICAL AND ORGANIZATIONAL SOLUTIONS - CALCULATION EXAMPLE}

The subject of assessment involves three variants of technical and organizational solutions (for mechanized longwall complexes):

- variant I (v I): KGS-260 longwall miner; longwall conveyor Rybnik 80; longwall support Glinik 0.8/22 Ozk,

- variant II (v II): KGS-245 longwall miner; longwall conveyor Rybnik-225/750/BP; longwall support Glinik 0.8/22 Ozk,

- variant III (v III): KGS-275/2B longwall miner; longwall conveyor Rybnik225/750/Poltrak II/N; longwall support Glinik 0.8/22 Ozk

which are applicable when the extraction involves the seam of the thickness of 1.5$1.9 \mathrm{~m}$ and seam inclination angle of $5-11^{\circ}$. The investigated seam is in the second category of methane hazard, class B of dust hazard and first level of rock burst hazard. The roof of the seam is made up by average layered clay shale and layers of sandy shale about $9.0 \mathrm{~m}$ thick, which makes it possible to apply the mining with caving.

Based on the opinion survey of experts (higher supervision staff of energy-mechanical and mining units, employees of the production preparation and investment departments), an eight-element set of features being the subject of the multi-criteria assessment was defined:

- financial expenditures (k1),

- daily mining output $(\mathrm{k} 2)$,

- unit cost of extraction (k3),

- number of people employed on the longwall (k4),

- safety (k5),

- comfort (k6),

- warranty conditions and service (k7),

- availability of spare parts (k8).

With reference to the first four of the above-mentioned features (measurable features), the Hellwig's method of development measure was used, and in the case of the other (qualitative features) - the multicriteria discrete method Promethe II was applied. The list of measurable criteria is presented in Table 1.

Table 1

List of quantitative criteria as part of a multicriteria assessment of technical and organizational solutions

\begin{tabular}{|c|c|c|c|}
\hline & Variant I (v I) & Variant II (v II) & Variant III (v III) \\
\hline Financial expenditures [PLN] & 39750000 & 37950000 & 40650000 \\
\hline Daily output [t/24h] & 3750 & 4200 & 4500 \\
\hline Unit cost [PLN/t] & 275 & 290 & 260 \\
\hline Longwall face staff & 54 & 58 & 48 \\
\hline
\end{tabular}

A summary of the significance (rank) of the criteria is presented in Table 2. 
Table 2

Summary of the significance (rank) of quantitative criteria

\begin{tabular}{|c|c|}
\hline Quantitative criterion & 0.8 \\
\hline Financial expenditures [PLN] & 0.7 \\
\hline Daily output [t/24h] & 0.8 \\
\hline Unit cost [PLN/t] & 0.6 \\
\hline Longwall face staff & \\
\hline
\end{tabular}

In the normalization process of variables, the ratio transformations were used.

On the basis of the normalized criteria, the distance between a given solution (equipment variant) and the ideal solution was calculated (Table 3).

\section{Table 3}

Ranking of objects (equipment variants) determined on the basis of measurable features (criteria k1-k4)

\begin{tabular}{|c|c|c|}
\hline Equipment variants & Development measure & Ranking of objects \\
\hline Variant III (v III) & 0.662 & 1 \\
\hline Variant II (v II) & 0.022 & 2 \\
\hline Variant I (v l) & 0.000 & 3 \\
\hline
\end{tabular}

In the case of quantitative criteria, we can conclude that the most advantageous solution is the purchase of option 3 (variant III is the most developed object), for which the value of the Hellwig's development measure is the closest to one $\left(m_{30}=0.662\right)$. The above assessment was supplemented with additional studies, in which four further criteria were considered, but of a qualitative nature:

- comfort (k5)

- safety (k6),

- warranty conditions and service (k7),

- availability of spare parts (k8).

The summary of the above three equipment variants in terms of the criteria $k 5-k 8$ are presented in Table 4 (in the assessment process, the scale from 0 (minimum grade) to 25 (maximum grade) was accepted.

Table 4

Assessment of individual variants in terms of criteria k5-k8

\begin{tabular}{|c|c|c|c|c|}
\hline & \multicolumn{5}{c|}{ Criterion } \\
\cline { 2 - 5 } & $\mathrm{k} 5$ & $\mathrm{k} 6$ & $\mathrm{k} 7$ & $\mathrm{k} 8$ \\
\hline Variant I (v I) & 25 & 25 & 15 & 10 \\
\hline Variant II (v II) & 25 & 25 & 14 & 12 \\
\hline Variant III (v III) & 25 & 25 & 18 & 11 \\
\hline
\end{tabular}

The significance coefficients for each of the qualitative criteria were respectively: $w_{5}$ $=0.25 ; w_{6}=0.25 ; w_{7}=0.25 ; w_{8}=0.25$.

As part of the example a generalized criterion of type 2 was used (quasi - criterion) for which the threshold of indifference (equivalence) $q=1$. In this case, the net flows were respectively: $\Phi(\mathrm{I})=-0.250 ; \Phi(\mathrm{II})=0.000 ; \Phi(\mathrm{III})=0.250$, which suggests that the option 3 is also the best choice for qualitative features.

\section{CONCLUSION}

Strong competition on the market and the determination to achieve the best economic results are increasingly enforcing the application of modern technical and organizational solutions. Therefore, as early as at the design and planning stages, 
multicriteria methods are applied, where the realization degree of an intended objective is measured by the function of the objective (criterion function) The methods presented in the article enable the generation of the final synthetic assessment for any number of features: the Hellwig's development measure method was applied to a set of quantitative (measurable) features, whereas the multicriteria discrete method Promethee II - to qualitative features. The Hellwig's development measure method synthesizes information from a series of diagnostic variables and assigns one aggregate measure to the analyzed phenomenon, whereas the Promethee II method makes it possible to determine the exceedance ratio (the differences between positive and negative flows of the preferences allow to determine net flows). Both of the above methods generate the ranking of objects (decision variants of mechanized longwall complexes) based on comparisons: in the case of the development measure method - by comparing objects (variants, longwall complexes) with the "ideal" solution, and in the case of the Promethee II method - by comparing all objects (variants, longwall complexes) pairwise with one another. The obtained final results $\left(m_{30}=0.662\right.$ and $\Phi$ $(\mathrm{III})=0.250$ ) allow to recommend the purchase of variant III, i.e. the longwall miner KGS-275/2B; a longwall conveyor Rybnik-225/750/Poltrak II/N and a longwall support Glinik 0.8/22 Ozk.

\section{REFEENCES}

Abedi, M., Torabi, A. S., Norouzi, G.-H., Hamzeh, M. and Elyasi, G.-R. (2012). A knowledgedriven method for copper exploration. Journal Computers \& Geosciences, 46, pp. 255263.

Brans, J.P. (1982). L'ingenierie de la decision, Elaboration d'instruments d'aide a la decision. La methode PROMETHEE. In: L'aide a la decision: Nature, Instruments et Perspectives d'Avenir. Quebec: Presses de l'Universite Laval, pp. 183-213

Brans, J. P., Mareschal, B. and Vincke, P. (1986). How to select and how to rank projects: The PROMETHEE method. European Journal of Operational Research, 24(2), pp. 228-238.

Brans, J. P. and Vincke, P. (2005). A preference ranking organisation method (The PROMETHEE method for multicriteria decision making). Management Science, 31(6), pp. 647-656.

Chmiela, A., Przybyła, H. (1997). Projektowanie rozwiązań techniczno-organizacyjnych stosowanych w wyrobiskach ścianowych. Gliwice: Wydawnictwo Politechniki Śląskiej.

Diakoulaki, D., Koumoutsos, N. (1991). Cardinal ranking of alternative actions: extension of the PROMETHEE method. European Journal of Operational Research, 53(3), pp. 337347.

Figueira, J., Greco, S. and Ehrgott M. (2005). Multiple Criteria Decision Analysis: State of the Art Surveys. Boston/Dordrecht/London: Kluwer Academic Publishers.

Geneletti, D. (2005). Multicriteria analysis to compare the impact of alternative road corridors: a case study in northern Italy. Impact Assessment and Project Appraisal, 23(2), pp. 135146.

Hellwig, Z. (1968). Zastosowanie metody taksonomicznej do typologicznego podziału krajów ze względu na poziom rozwoju oraz zasoby i strukturę wykwalifikowanych kadr. Przegląd Statystyczny, 4, pp. 307-326.

Górecka, D. (2010). Zastosowanie metod wielokryterialnych opartych na relacji przewyższania do oceny europejskich projektów inwestycyjnych. Metody i zastosowania badań operacyjnych, 10, pp. 100-125.

Górecka, D., Muszyńska, J. (2011). Analiza przestrzenna innowacyjności polskich regionów. Acta Universitatis Lodziensis Folia Oeconomica, 253, pp. 55-70.

Górecka, D., Szałucka, M. (2013). Country market selection in international expansion using multicriteria decision aiding methods. Multiple Criteria Decision Making, 8, pp. 31-55.

Kozdrój, M. Przybyła H. (1986). Teoria organizacji i zarządzania. Cz. III Modele matematyczne w organizacji produkcji górniczej. Gliwice: Skrypty uczelniane Politechniki Śląskiej. 
Mynarski, S. (1992). Badania przestrzenne rynku i konsumpcji. Przewodnik metodyczny. Warszawa: Wydawnictwo Naukowe PWN.

Nowak, M. (2005). Investment project evaluation by simulation and multiple criteria decision aiding procedure. Journal of Civil Engineering and Management, 11, pp.193-202.

Przybyła, H., Korban, Z. (2003). Wykorzystanie sondażu opinii ekspertów w procesie zarządzania bezpieczeństwem pracy. Zeszyty Naukowe Politechniki Śląskiej seria Górnictwo, 258, pp. 519-527.

Przybyła, H., Korban, Z. (2004). Wybrane metody matematyczne w analizie i ocenie ryzyka zawodowego. Zeszyty Naukowe Politechniki Śląskiej, seria Górnictwo, 261, pp. 521528.

Roy, B. (1990). Wielokryterialne wspomaganie decyzji. Warszawa: Wydawnictwo NaukowoTechniczne.

Vijay, M. A., Shankar, Ch. (2010). Facility Location Selection using PROMETHEE II Method. In: Proceedings of the 2010 International Conference on Industrial Engineering and Operations Management. Dhaka, Bangladesh, pp. 59-64.

Vincke, P. (1992). Multicriteria decision-aid. Chichester: John Wiley.

\begin{abstract}
Making decisions is a process that involves taking into account $n$ acceptable variants of undertaken actions in view of $\mathrm{m}$ adopted assessment criteria and selecting the optimal variant (optimal variants). Due to the number of alternatives being assessed and the number of considered criteria, more and more frequently mathematical methods are used in this process. Basing on the example involving the selection of a mechanized longwall complex, the article presents the application of selected multicriteria methods: in the case of quantitative features - Hellwig's development measure method, and in the case of qualitative features - Promethee II method. In the case of Hellwig's development measure method, equipment variants were interpreted as points $w$ in the multidimensional space, and then the distances between them and the point Po (perfect solution) were determined. In the case of the Promethee II method (discrete multicriteria decision support method), the equipment variants were compared with each other in pairs, which made it possible to determine the so-called net flows $\Phi(\mathrm{i})$. The obtained synthetic values mi and $\Phi(\mathrm{i})$ allowed to build rankings of equipment variants (objects) and to indicate the optimal variant.
\end{abstract}

Keywords: making decisions, the multicriteria methods 